Print ISSN: 2502-1397 / Online ISSN 2540-8100

https://doi.org/10.32505/j-ebis.v6i2.3530

\title{
PERFORMA MODAL BANK SYARIAH \\ DI TENGAH PANDEMI COVID-19
}

\author{
Tri Inda Fadhila Rahma \\ Universitas Islam Negeri Sumatera Utara, triindafadhila@uinsu.ac.id
}

\begin{abstract}
Capital is a very important function in overcoming risks that may occur in Banking Industry. A bank is categorized to be healthy if a bank has sufficient capital despite possible risks that may happen. Capital indicators are determined as the key measurement to analyse the status of a bank. The capital adequacy ratio or Capital Asset Ratio (CAR) is utilised in this research. Factors that can affect the size of the capital adequacy ratio are originated from internal and external. Internal factors originated from the banking industry itself, such as profitability, asset quality, company size and liquidity. Meanwhile, external factors come from outside the company such as the macroeconomic condition of a country. The Covid-19 pandemic is one of the impacts that causes the economic condition of one to weaken which also impacts on investment. Hence, this study aims to analyse the performance of Islamic banks during Covid-19 Pandemic in Indonesia from February to the end of 2020 as well as Factors that influence the size of capital adequacy ratio. The findings show that during the Covid-19 pandemic, Islamic banking was able to show its performance as an ever-growing Islamic financial institution which is seen from the data of assets development as well as growth in deposits. CAR of Islamic banking in 2020 remains at a fairly strong level despite the covid-19 pandemic. The internal factor which influence CAR is Return On Assets (ROA) with a significance value of 0.005 .
\end{abstract}

Keyword: Modal, CAR, ROA, FDR

\begin{abstract}
ABSTRAK
Modal merupakan fungsi yang sangat penting dalam mengatasi resiko yang bisa saja terjadi pada Industri Perbankan. Bank dikatakan sehat apabila suatu bank tersebut memiliki modal yang cukup walaupun terjadinya kemungkinankemungkinan resiko. Untuk melihat bank itu sehat juga menjadikan indikator modal sebagai pengukuran yang paling penting yakni melalui rasio kecukupan modal atau Capital Asset Ratio (CAR). Hal yang dapat mempengaruhi besar kecilnya rasio kecukupan modal bisa terjadi disebabkan faktor Internal maupuun Eksternal. Faktor Internal yang berasal dari Industri perbankan itu sendiri seperti Profitabilitas, kualitas asset, ukuran perusahaan dan Likuiditas. Sedangkan faktor eksternal yang berasal dari luar industri perbankan yakni keadaan makroekonomi suatu Negara. Pandemic Covid-19 merupakan salah satu dampak yang menyebabkan keadaaan ekonomi suatu Negara melemah yang berimbas pada investasi. Maka penelitian ini bertujuan untuk memaparkan
\end{abstract}


seberapa besar kemampuan Bank Syariah ditengah terjadinya Pandemi Covid19 yang mulai terjadi di Indonesia sejak bulan Februari 2020 sampai dengan akhir tahun 2020. Dan faktor yang mempengaruhi besar kecilnya rasio kecukupan modal. Hasil penelitian dalam penelitian ini memaparkan bahwa pada masa pandemic covid-19 perbankan syariah mampu menunjukkan performanya sebagai lembaga keuangan syariah yang terus berkembang dilihat dari data perkembangan Aset dan pertumbuhan DPK. CAR perbankan syariah periode tahun 2020 tetap berada pada level yang cukup kuat meskipun dalam keadaan pandemi covid-19. Sedangkan salah satu faktor internal yang mempengaruhi CAR adalah Return On Asset (ROA) dengan nilai signifikansi sebesar 0.005 .

Keyword: Modal, CAR, ROA, FDR

\section{PENDAHULUAN}

Pandemi covid-19 merupakan keadaan dimana terjadinya penyebaran wabah virus corona yang terjadi di seluruh dunia, dikarenakan penyebarannya yang cepat meluas sehingga pemerintah Internasional mencoba untuk memutus rantai penyeberan virus corona dengan membuat berbagai aturan mengenai pembatasan aktivitas masyarakat. Akibat pandemic ini maka berdampak kepada keadaan ekonomi maupun social, namun sangat berdampak luas terhadap melemahnya perekonomian suatu Negara.

Menurut Direktur Jenderal Pajak Kementerian Keuangan oleh Suryo Utomo, pademi covid -19 berdampak besar kepada perekonomian, yakni pertama menurunkan konsumsi masyarakat, BPS telah mencatat bahwa aktivitas ekonomi rumah tangga menurun di kuartal I tahun 2019 dari 5,02\% ke 2,84\% pada kuartal I di tahun ini. Kedua, tidak ada kepastian pandemic covid akan berakhir menyebabkan menurunnya investasi yang berdampak pada terhentinya usaha, hal ini dapat dilihat pada fenomena yang terjadi yakni banyaknya perusahaan yang mengalami kebangkrutan karena kurangnya investasi dan karyawan yang pada akhirnya diberhentikan. Ketiga, pandemic ini tidak hanya berdampak pada Negara Indonesia saja melainkan juga diseluruh dunia sehingga perekonomian dunia juga ikut melemah, hal ini menyebabkan menurunnya harga komoditas dan ekspor Indonesia ke Negara lain mengalami pelemahan. 
Perbankan salah satu industri yang ikut merasakan dampaknya pandemic covid-19, karena perbankan adalah lembaga keuangan yang mengumpulkan dana masyarakat. Ekonomi sektor saat ini mengandalkan lembaga keuangan seperti perbankan untuk mendukung kehidupan masyarakat sehari-hari aktivitas ekonomi. Hal ini diperkirakan akan mempengaruhi baik sektor makro maupun mikro (Yulia dan Ramdani, 2020). Dari sektor keuangan yang terus beroperasi, bank umum syariah (BUS) juga terkena dampak pandemi. Setidaknya 14 BUS di Indonesia per Juli 2019 terkena goncangan pandemi COVID-19 (Wahyudi dan Husnayeni, nd). Rahman (2020) menyatakan BUS mengalami guncangan di sektor pembiayaan, pembiayaan di sisi mudharabah mengalami penurunan, berbanding terbalik dengan murabahah yang terus meningkat. Jika ini terus berlanjut, maka kemungkinannya akan mempengaruhi sisi beban biaya operasional bank, yang akan berdampak pada profitabilitas. Bukan hanya BUS yang terkena pandemi, tapi bank konvensional juga mengalami beberapa guncangan (Ferdinandus dan Unpatti, 2020).

Perbankan merupakan suatu lembaga yang menjadi penghubung atau mediator bagi masyarakat yang mempunyai dana atau kelebihan dana dengan masyarakat yang membutuhkan dana atau kekurangan dana, sehingga perbankan pada kegiataannya dana dihimpun dari masyarakat dan disalurkan kembali ke masyarakat. Pada kegiataannya secara umum bank syariah sama seperti bank konvensional. Sehingga pada umumnya dalam proses kegiatannya bank harus dapat menghadapi kemungkinan terjadinya resiko seperti gagal bayar, likuiditas dan resiko lainnya. Oleh karena itu bank harus berhati-hati (prudent) dalam menjalankan usahanya. (Wahyudi: 2013)

Salah satu aspek perbankan yang menarik perhatian pengambil kebijakan adalah peningkatan permodalan. Sebagaimana telah disebutkan (Siamat: 2004), masalah permodalan ini penting dalam kaitannya dengan fungsi utamanya untuk melindungi setiap nasabah jika suatu bank mengalami kerugian melebihi jumlah yang diprediksi sebelumnya. Hal ini menjadikan permodalan bank sebagai salah satu aspek terpenting bagi bank untuk 
mendapatkan kepercayaan masyarakat. Selain itu, modal bagi bank untuk mendukung rencana ekspansi juga penting (Muhammad: 2002). Capital adequacy ratio (CAR) (Rivai: 2013) sebagai ukuran apakah suatu bank mempunyai kecukupan modal dan cadangan untuk mengambil berbagai resiko.

Penilaian integritas Bank Indonesia saat ini didasarkan pada faktor CAMEL (modal, kualitas aset, manajemen, pendapatan, likuiditas). Kelima faktor tersebut menentukan kesehatan suatu bank. Jika bank memiliki masalah yang terkait dengan salah satu faktor ini, itu akan bermasalah. Sederhananya, bank dinyatakan sehat apabila bank dapat memelihara kepercayaan masyarakat, bertindak sebagai perantara, berkontribusi pada kelancaran pembayaran, dan tersedia bagi pemerintah untuk menerapkan berbagai kebijakan.

Bank Indonesia telah meluncurkan program Arsitektur Bank Indonesia (API) untuk membangun sistem perbankan yang tangguh. Ini merupakan program restrukturisasi perbankan secara nasional dengan tujuan untuk menguatkan permodalan bank untuk meningkatkan kemampuan bank dalam menjalankan bisnis dan risikonya. Inisiatif negara lainnya adalah diterbitkannya Peraturan Bank Indonesia Nomor: 6/10/PBI/2004 melalui sistem penilaian integritas bank umum. Salah satu aturannya adalah mengatur modal minimum bank (CAR) menjadi $8 \%$.

Perbankan dalam mengukur kecukupan modal dapat dilakukan dengan menggunakan CAR untuk mengetahui rasio modal dengan asset masing-masing perbankan. Penilaian ini mengukur dengan cara yakni modal dibandingkan dengan DPK serta modal dibandingkan dengan asset berisiko. Namun CAR suatu bank syariah harus memperhatikan faktor yang mempengaruhinya. Salah satunya adalah faktor internal dari perbankan syariah tersebut yakni mempertimbangkan kesehatan perbankan meliputi profitabilitas, likuiditas dan efesiensi. CAR suatu bank dikatakan sehat apabila bank tersebut dapat menghasilkan keuntungan yang disebut dengan profitabilitas. Penilaian dapat didasarkan pada rasio pengembalian asset atau yang disebut dengan return on 
asset (ROA). Untuk menumbuhkan kepercayaan masyarakat agar mau menginvestasikan dananya di bank maka perbankan syariah harus dapat meningkatkan profitabilitas dengan mengelola likuiditas perbankan.

Menurut Willara, fenomena rendahnya likuiditas perbankan Indonesia akibat kekurangan CAR terlihat dari adanya kaitan antara rasio likuiditas dengan CAR, yaitu bagaiman bank mampu untuk memenuhi kewajiban penagihan jangka pendeknya (Kasmir: 2009). Likuiditas digambarkan dengan rasio pendanaan (FDR) terhadap simpanan, yaitu rasio jumlah total dana yang diberikan terhadap dana yang diterima oleh bank (Dendawijaya: 2011). Sehingga diketahui bahwa terdapat hubungan antara FDR dan CAR, yaitu ketika FDR meningkat karena modal yang dihimpun meningkat dan modal yang dihimpun rendah maka dapat terjadinya penurunan CAR (dengan asumsi CAR dimanfaatkan untuk menutup kurangnya dana).

BOPO dapat diukur dengan cara rasio efisiensi. Rasio ini memperkirakan apakah manajemen industri perbankan telah memanfaatkan semua faktor produksi secara efisien. Sementara itu, kinerja bisnis bank diukur dengan biaya operasional dibandingkan laba operasi (BOPO). BOPO adalah perbandingan antara beban usaha dan laba usaha. Rasio ini digunakan untuk menghitung efesiensi dan kapasitas bank dalam menjalankan kegiatannya yaitu perkreditan (Dendawijaya: 2011). Maka secara teori BOPO memiliki hubungan dengan CAR, apabila bank dapat menghasilkan keuntungkan yang efesien melalui biaya operasional maka semakin banyak modal yang diinvestasikan.

Persentase tingkat profitabilitas bank syariah dapat dilihat dari besarnya pertumbuhan laba, biaya operasional, dana pihak ketiga, dan NPF (Novitasari, 2015). Kemampuan bank untuk menghasilkan keuntungan merupakan indikator kinerja yang baik. Sebaliknya, biaya operasional dapat timbul dari berbagai operasional perusahaan (Fithriyanto, 2021). NPF atau kredit macet adalah pembiayaan yang tidak sesuai dengan harapan bank, semakin tinggi NPF sejalan dengan tingginya risiko pembiayaan (Meutia Fitri, 2016). Ilhami dan Thamrin (2021) menyatakan bahwa pandemi tidak berdampak signifikan terhadap kinerja perbankan syariah, didukung oleh Sumadi (2020) dalam penelitiannya; 
mulai dari bulan januari sampai maret 2020 terdapat fluktuasi terutama pada dana pihak ketiga (DPK). Untuk mengatasi pandemi ini, BUS mengintensifkan aplikasi digital untuk mendukung program Work From Home (WFH). Oleh karena itu, perlu diketahui performa permodalan bank syariah pada masa pandemi COVID-19 dan faktor internal yang mempengaruhi fluktuasi koefisien CAR.

\section{LANDASAN TEORETIS}

Keberhasilan dari kegiatan badan usaha dapat dinilai dengan melakukan penilaian kinerja setiap perusahaan. Setiap perbankan secara khususnya diatur oleh Bank Indonesia sebagai bank sentral perbankan secara umum. Beberapa aspek yang dapat menilai tingkat kinerja perbankan terdiri dari permodalan, Kualitas Aktiva Produktif, Manajemen, Rentabilitas dan Likuiditas. Maka dalam penelitian ini meninjau mengenai permodalan bank syariah secara umum di Indonesia.

\section{Modal}

Modal adalah bagian terpenting terhadap meningkatnya pelaksanaan kegiatan perusahaan selain faktor produksi sumber daya manusia, mesin, material dan metode. Perusahaan akan membuat suatu keputusan modal perusahaannya dengan menghubungkan sumber dana yang berasal dari internal maupun eksternal perusahaan.

Modal merupakan penyerahan dana dari pemilik dana kepada pengelola. Kemudian pemilik dana akan menerima sebagian dari hasil kinerja setiap akhir tahun buku yang disebut dengan dividen. Modal tersebut dimanfaatkan oleh pengelola dalam hal ini perusahaan untuk membeli bangunan, tanah, peralatan, atau yang lainnya yang tidak menghasilkan pendapatan langsung. Disamping itu modal juga bisa dimanfaatkan untuk tujuan produktif dan diarahkan pada penghimpunan dana dari modal. Hasil yang diperoleh dapat dibagikan kepada pemilik modal, bukan kepada pemilik dana lain (Antonio: 2004). 
Modal juga dapat didefinisikan sebagai mewakili kepentingan pemilik perusahaan. Berdasarkan nilai buku, defenisi dari modal ialah sebagai kekayaan bersih. Ini adalah nilai buku aset dikurangi nilai buku kewajiban (Arifin: 2006). Pemegang saham menginvestasikan modal di bank untuk keuntungan masa depan. Neraca berfokus pada sisi utang bank: akun modal dan akun cadangan. Rekening modal berasal dari kontribusi sekutu dan rekening cadangan berasal dari bagi hasil yang tidak dibagikan kepada sekutu. Ini dimanfaatkan untuk tujuan tertentu seperti memperluas bisnis atau mempertahankan likuiditas yang mengarah ke pinjaman atau kerugian yang mencurigakan.

\section{Sumber Dana Bank Syariah}

Sumber dana Bank Syariah paling besar adalah bersumber dari masyarakat sendiri, selain itu dana lainnya yang berasal dari modal sendiri maupun pinjamanan. Berikut sumber dana bank syariah yang terdiri dari terdiri dari: (Muhammad: 2014)

a. Modal inti merupakan para pemegang saham memberikan kontribusi dana kepada perbankan syariah atau dapat disebut dengan pemilik bank tersebut. (Muhammad: 2002). Modal inti terdiri dari:

1) Setoran modal dari para pemegang saham, hal ini dikarenakan sumber dana utama dari modal perusahaan adalah saham.

2) Cadangan, yaitu bagian keuntungan bank yang tidak dibagikan yang digunakan untuk menutupi resiko kerugian di masa depan.

3) Laba ditahan, yaitu Ini adalah bagian dari keuntungan yang telah diputuskan oleh para pemegang saham sendiri agar diinvestasikan kembali di bank (melalui rapat pemegang saham), meskipun itu dimaksudkan untuk dibagikan kepada pemegang saham.

b. Kuasi ekuitas (mudharabah account)

Kuasi ekuitas dalam perbankan syariah dengan melakukan penghimpunan dana berdasarkan prinsip akad mudharabah. Mudharabah ialah suatu akad kerjasama antar shohibul mal atau pemilik modal dan mudharib atau pengelola modal dengan kesepakatan bagi 
hasil keuntungan antara kedua belah pihak tersebut sedangkan kerugian dari segi keuangan atau finansial ditanggung oleh pemilik dana dan pengelola menanggung kerugian dari segi tidak dapat memperoleh keuntungan. Dimana bank merupakan pengelola modal kemudian nasabah sebagai pemilik modal. Maka bank dan nasabah membuat kesepakatan bagi hasil dari pendapatan yang diperoleh perbankan terhadap pengelolaan dana tersebut. Produk bank syariah untuk akad tersebut terdiri dari :

1) Rekening investasi umum

2) Rekening investasi khusus

3) Rekening tabungan mudharabah

4) Rekening Giro Mudharabah

c. Titipan (wadi'ah) atau simpanan tanpa imbalan

Dana titipan adalah dana pihak ketiga yang disimpan di bank, biasanya dalam bentuk giro atau tabungan. Motivasi utama masyarakat untuk menyimpan dana di bank adalah keamanan dana dan kebebasan untuk menarik dana setiap saat. Bank syariah dalam mengelola simpanan nasabah menggunakan akad wadi'ah. Dimana akad wadi'ah yang digunakan adalah wadiah yad adh -dhamamah. Wadiah yad adh-dhamamah merupakan akad titipan suatu barang atau uang kepada pihak penerima titipan dan penerima titipan dapat menggunakan barang yang dititip dan pemegang titipan wajib bertanggung jawab atas barang tersebut apabila terjadi kerusakan atau kehilangan. Penerima titipan mendapatkan hak atas manfaat serta keuntungan barang titipan tersebut. (Zulkifli, 2003).

Dari dana wadi'ah tersebut maka bank mengelola dana titipan nasabah sebagai bentuk pemanfaatan barang titipan. Dari pengelolaan uang simpanan nasabah maka bank akan memeperoleh keuntungan yang menjadi kepemilikan bank, dan bank harus menanggung kerugian karena nasabah mendapatkan jaminan atas pengembalian uang simpanannya. 
Seperti pada produk tabungan dan giro sebagai titipan wadi'ah yad dhmanah.

Selama uang simpanan nasabah dititipkan kepada bank maka bank dapat memanfaatkan dana tersebut dan bank tetap wajib mengembalikan dana setiap saat ketika nasabah ingin mengambil kembali uang simpanannya. Bank dapat memberikan imbalan berupa bonus kepada nasabah sebagai jasa atas penggunaan barang titipan. Namun bank tidak dapat melakukan perjanjian di awal dengan nasabah karena tidak ada keharusan bank dapat memberi atau tidak imbalan tersebut kepada nasabah.

\section{Faktor - Faktor Yang Mempengaruhi CAR}

CAR dipengaruhi oleh beberapa variabel salah satunya ialah Return on Assets (ROA), Financing to deposit ration (FDR) dan Biaya Operasional dan Pendapatan Operasional (BOPO). Return On Assets (ROA) setiap perusahaan menunjukkan seberapa efektif perusahaan menggunakan asetnya untuk menghasilkan keuntungan; persamaannya adalah laba bersih atas total aktiva. (Hong, 2020) Rasio permodalan (capital), Kualitas Aktiva Produktif (Asset Quality), manajemen (management), Pendapatan (Earning), Likuiditas (liquidity) telah ditetapkan oleh otoritas moneter di Indonesia.

Semakin tinggi tingkat CAR berarti bank syariah dapat membiayai produktivitasnya. Sebaliknya, jika CAR rendah, akan membutuhkan banyak biaya untuk mendukung produktivitas; ini akan mempengaruhi rendah keuntungan yang diperoleh (Mandiri et al., 2013).

Menurut Almunawwaroh dan Marliana (2018), FDR adalah rasio total dana yang diterima bank terhadap total pembiayaan yang telah dikeluarkan. Semakin tinggi tingkat FDR menunjukkan rendahnya likuiditas suatu bank dan sebaliknya. NPF mencerminkan tingkat pembiayaan bermasalah pada suatu bank. Semakin rendah tingkat NPF maka semakin baik kinerja suatu perbankan. 
Dengan demikian, semakin tinggi rasio FDR, semakin rendah likuiditasnya. Namun, di sisi lain, rasio FDR yang tinggi juga mengindikasikan aliran masuk modal bank yang besar. Semakin besar jumlah yang diterima bank, semakin besar risiko yang ditanggung. Risiko seperti ketidakaktifan modal dan risiko kredit dapat mempersulit bank untuk membayar kembali simpanan nasabah. Penyebabnya antara lain kegagalan kredit atau pinjaman yang tidak efisien.

Untuk melihat seberapa efesien dan efektif suatu bank maka diukur dengan rasio efisiensi yakni membandingkan biaya operasional dibandingkan dengan pendapatan operasional. Semakin tinggi nilai BOPO maka semakin tidak efisien operasional bank tersebut. Biaya operasional terhadap pendapatan operasional atau disingkat BOPO adalah rasio profitabilitas bisnis yakni perbandingan antara biaya operasional dengan pendapatan operasional. Melalui BOPO maka dapat terlihar bagaimana perusahaan mampu untuk mengelola biaya operasional. Semakin tinggi biaya operasional, semakin buruk manajemen perusahaan.

\section{METODE}

Pendekatan penelitian dalam penelitian ini ialah dengan jenis pendekatan penelitian deskriptif kuantiatif yang di gambarkan melalui data angka yang ditampilkan dalam bentuk tabel dan grafik. Kemudian untuk menganalisis pengaruh faktor yang mempengaruhi dapat dianalisis dengan analisis regresi sederhana melalui program SPSS. Kemudian data yang digunakan dalam penelitian adalah data dari tahun 2018 sampai tahun 2020 yang diambil dari data publikasi Otoritas Jasa Keuangan (OJK).

\section{HASIL DAN PEMBAHASAN}

\section{Modal Perbankan Syariah di Masa Pandemic Covid-19}

Dana merupakan uang tunai yang dipegang atau dikendalikan oleh bank dalam bentuk uang tunai atau aset lain yang langsung dapat dikonversi menjadi uang tunai. Kas yang dimiliki atau dikuasai oleh bank tidak hanya dari pemilik 
bank itu sendiri, tetapi juga dari simpanan atau dana penyertaan pihak lain atau pihak lain yang sewaktu-waktu atau pada suatu waktu tertentu akan dieliminasi, baik sekaligus maupun bertahap. Dana terlihat di sisi kewajiban neraca juga dikenal sebagai manajemen kewajiban yang merupakan proses di mana bank berusaha mengembangkan sumber dana tradisional melalui pinjaman di pasar uang atau dengan menerbitkan surat utang untuk penggunaan yang menguntungkan, yaitu untuk memenuhi alokasi yang diamortisasi.

Sampai dengan Agustus 2020 modal bank syariah pada Statistik Perbankan Syariah sebesar Rp 42846,1438244 Milliar. Sedangkan total asset bank syariah sebesar Rp 358.851 Milliar. Berikut grafik pengembangan modal bank syariah sejak tahun 2019.

\section{Grafik 1. Modal Bank Syariah}

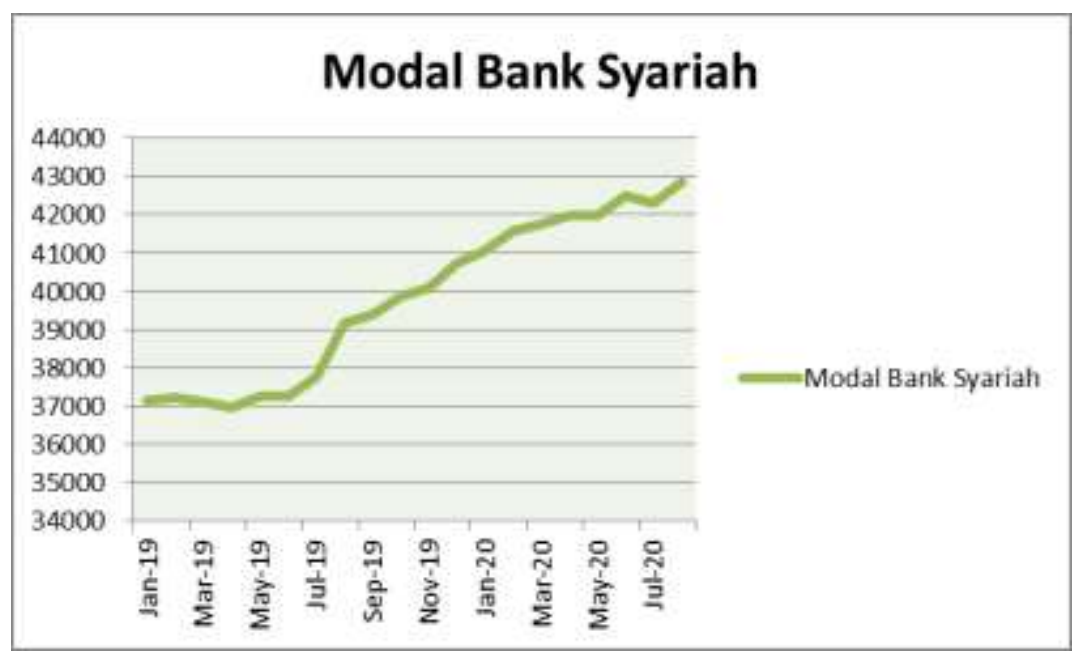

Jika dilihat dari grafik di atas bahwa perkembangan modal Bank Syariah di Indonesia terus mengalami kenaikan sampai di akhir bulan Agustus tahun 2020, meskipun pada bulan Juni tahun 2020 ada penurunan namun tidak terlalu signifikan dan terus meningkat sampai Agustus tahun 2020. Hal ini dapat disimpulkan bahwa tidak ada dampak Pandemi Covid-19 pada perkembangan modal Bank Syariah di Indonesia. Bank Syariah tetap menunjukkan perkembangan modalnya yang semakin meningkat. Dari sisi aset, bank syariah mencatat pertumbuhan yang lebih tinggi, meningkat 10,97\% year-on-year, dibandingkan dengan bank konvensional yang tumbuh 7,7\% year-on-year. Sama 
halnya dengan penelitian yang dilakukan oleh Ilhami dan Thamrin yang menyatakan bahwa pandemi tidak berdampak signifikan terhadap kinerja perbankan syariah.

Apabila dilihat dari segi Dana Pihak Ketiga menurut Otoritas Jasa Keuangan (OJK) telah mencatat pertumbuhan DPK perbankan syariah pada Agustus 2020 sebesar Rp 430,209 trilliun, naik dari 2019 sebesar Rp 425,29 trilliun. Dana pihak ketiga bank syariah pada periode yang sama mencatat pertumbuhan tahunan sebesar $11,56 \%$, sedikit lebih tinggi dibandingkan peningkatan DPK bank konvensional sebesar $11,49 \%$.

Artinya masyarakat tetap merasa aman dengan berinvestasi di perbankan Syariah meskipun adanya pandemic Covid-19. Berikut grafik mengenai pertumbuhan Dana Pihak Ketiga (DPK) sejak tahun 2019 sampai tahun 2020.

\section{Grafik 2 . Total DPK}

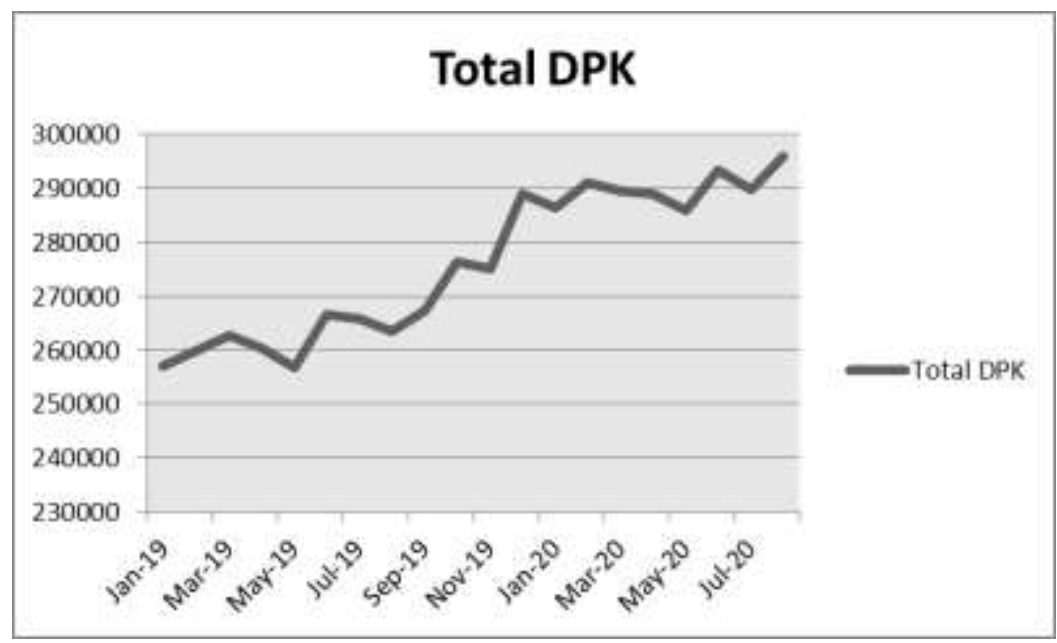

Sementara itu, pangsa pasar (Market Share) bank syariah pada Juni 2020 sebesar 6,18\% dibandingkan bank konvensional. Pangsa tersebut berasal dari bank umum syariah sebesar 65,33 persen, unit usaha syariah 32,17 persen, dan bank syariah sebesar 2,5 persen. Oleh karena itu, bank syariah merupakan penyumbang terbesar bagi perkembangan keuangan syariah di Indonesia.

Indikator pengukur kesehatan bank syariah dilihat dari sisi Capital Adequacy Ratio (CAR) pada perbankan syariah di Indonesia dapat dilihat pada 
tabel Rasio Keuangan Bank Syariah pada Statistik Perbankan Syariah yang dipublikasi oleh Otoritas Jasa Keuangan (OJK). Maka posisi CAR dapat dilihat pada grafik yang diolah sebagai berikut.

\section{Grafik 3. Data Capital Adequacy Ratio (CAR) pada Bank Syariah di Indonesia}

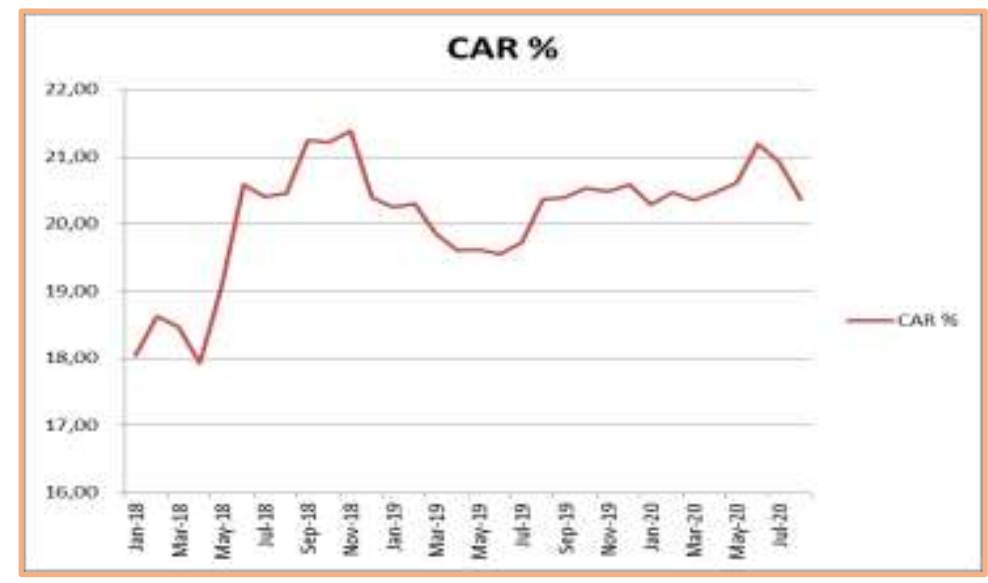

Pada grafik di atas terlihat terjadi penurunan di bulan Januari ke Maret tahun 2019, dan terjadi peningkatan pada periode Maret ke Mei tahun 2020. Tahun 2020 sedang mengalami pandemic Covid-19, namun tidak berdampak pada CAR Perbankan Syariah, berbeda dengan Bank Konvensional, pandemi tersebut sangat berdampak pada CAR perbankan konvensional, grafik dapat dilihat sebagai berikut.

\section{Grafik 4. Data Capital Adequacy Ratio (CAR) pada Bank Konvensional di} Indonesia

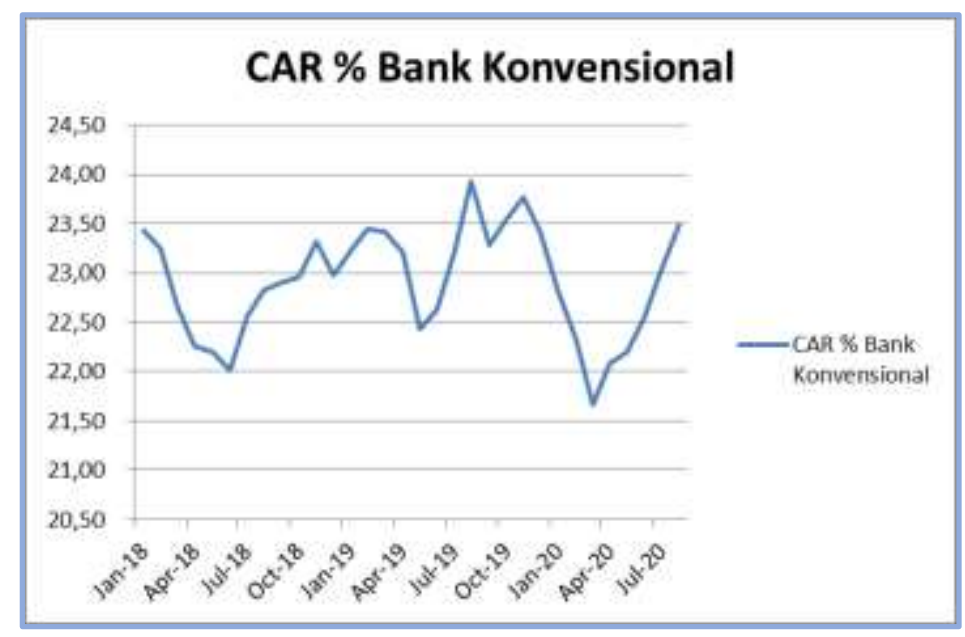


Dari grafik tersebut terlihat bahwa lonjakan penurunan CAR pada perbankan konvensional terjadi pada periode Januari ke April tahun 2020, disebabkan peraturan pemerintah tentang Pembatasan Sosial Berskala Besar (PSBB), sehingga sangat mempengaruhi perekonomian Negara. Hal ini berdampak pada Bank Konvensional untuk pengembalian pinjaman atau kredit. Sedangkan pada Bank Syariah tidak terlalu berdampak seperti yang dinyatakan oleh Senior Faculty LPPI Amin Nurdin, bahwa Rasio permodalan bank syariah di tengah pandemi cukup tinggi. Pemilik bank syariah cukup konsisten dalam perkembangannya sehingga tidak terburu-buru membayar dividen. Tahun ini, meski tumbuh moderat, kualitas pembiayaan bank syariah cukup baik, sehingga rasio solvabilitas menguat.

\section{Faktor yang mempengaruhi Modal bank Syariah di Masa Pandemic Covid-19}

Kecukupan modal sangat penting dalam industri perbankan. Bank dengan kecukupan modal yang baik menunjukkan bahwa ini adalah bank yang sehat. Karena kecukupan modal suatu bank mewakili posisinya yang dinyatakan dengan rasio kecukupan modal (CAR). Maka kecukupan modal perbankan dapat diukur dengan:

a. Modal dibandingkan dengan dana pihak ketiga

Dilihat dari segi deposan, apabila modal dibandingkan dengan kewajiban yang merupakan indikator keamanan simpanan masyarakat di bank. Perhitungan rasio modal yang melekat pada simpanan pihak ketiga (giro, deposito berjangka dan tabungan) adalah sebagai berikut:

Modal dan Cadangan= 10\%Giro+Deposito+Tabungan

Dari perhitungan tersebut diketahui bahwa rasio modal/tabungan cukup.10 persen dengan rasio ini, modal bank adalah dianggap sehat, dikombinasikan dengan pertimbangan aset berisiko. Oleh karena itu, modal harus lengkap dengan berbagai cadangan sebagai penyangga modal, sehingga pada umumnya modal bank terdiri dari modal inti dan modal tambahan. 
b. Membandingkan modal dengan aktiva berisiko

BIS (bank for International Settlements) yang merupakan organisasi bank sentral yang berasal dari Negara-negara maju seperti Amerika Serikat, Kanada, Negara Eropa dan Jepang telah menyepakati tentang kecukupan permodalan yang mengatur rasio CAR, yaitu rasio minimum berdasarkan rasio modal terhadap aktiva berisiko. Kesepakatan ini dilatarbelakangi oleh pengamatan para pakar perbankan di negara maju, termasuk dari IMF dan Bank Dunia, tentang adanya ketidakseimbangan struktural dan sistemik sistem perbankan internasional. Seperti terjadinya persaingan tidak sehat antar ban jepang dengan Amerika di pasar mata uang internasional dan keadaan lainnya yang mengganggu perdagangan internasional. Maka BIS menetapkan aturan untuk menghitung Capital Adequacy Ratio (CAR) yang harus diikuti oleh bank-bank di seluruh dunia agar dapat bersaing secara sehat di pasar keuangan secara global, yaitu minimal tingkat modal 8\% terhadap aktiva berisiko. (Arifin: 2002).

Untuk melihat pengaruh ROA terhadap CAR pada periode tahun 2018 sampai tahun 2020 dapat dilihat sebagai berikut.

Tabel 1. Uji t ROA terhadap CAR

Coefficients $^{a}$

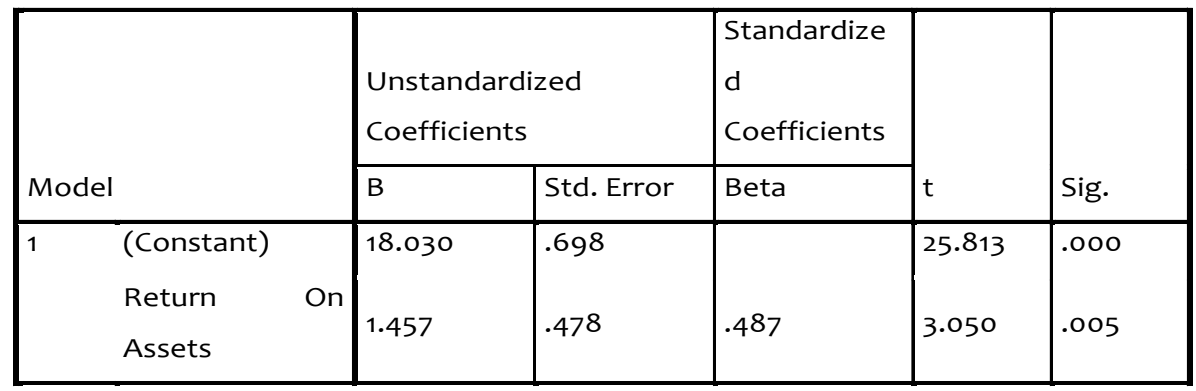

a. Dependent Variable: Capital Adequacy Ratio

Dari hasil uji t pada tabel 1 di atas terlihat bahwa nilai signifikansi sebesar 0.005 lebih besar dari taraf nyata 0.05 atau 5\%. Maka dapat disimpulkan bahwa ROA berpengaruh terhadap CAR. Apabila ROA mengalami peningkatan sebesar 1\% maka akan meningkatakan CAR sebesar 1.457. Sehingga CAR ditentukan oleh besar kecilnya kemampuan perbankan dalam menghasilkan keuntungan. 
Seperti penelitian yang dilakukan oleh Rachmat Ramadhani, bahwa Return On Assets (ROA) adalah variabel yang paling berpengaruh terhadap CAR.

Bank dalam meningkatkan profitabilitas harus memperhatikan seberapa besar tingkat likuiditasnya. Adanya fakta yang terjadi bahwa di Indonesia untuk perbankan yang tidak likuid disebabkan CAR bank tersebut tidak cukup, sehingga terdapat hubungan antara rasio likuiditas dengan CAR. Likuiditas perbankan dapat digambarkan melalui FDR. Berikut tabel 2 menjelaskan hasil uji t pengaruh FDR terhadap CAR.

Tabel 2. Uji t FDR terhadap CAR

Coefficients $^{\mathrm{a}}$

\begin{tabular}{|c|c|c|c|c|c|c|}
\hline \multirow{2}{*}{\multicolumn{2}{|c|}{ Model }} & \multicolumn{2}{|c|}{$\begin{array}{l}\text { Unstandardized } \\
\text { Coefficients }\end{array}$} & \multirow{2}{*}{$\begin{array}{l}\text { Standardize } \\
\text { d } \\
\text { Coefficients } \\
\text { Beta }\end{array}$} & \multirow[b]{2}{*}{$\mathrm{t}$} & \multirow[b]{2}{*}{ Sig. } \\
\hline & & B & Std. Error & & & \\
\hline \multirow[t]{2}{*}{1} & (Constant) & 5.618 & 10.156 & & .553 & .584 \\
\hline & $\begin{array}{l}\text { Financing to Deposit } \\
\text { Ratio }\end{array}$ & .183 & & .252 & 1.428 & .164 \\
\hline
\end{tabular}

a. Dependent Variable: Capital Adequacy Ratio

Dari hasil olah data pada tabel 2 di atas bahwa FDR tidak berpengaruh terhadap CAR, dilihat dari significancy sebesar 0.164 , artinya meskipun bank syariah mengalami tidak likuid namun tetap mencukupi modal. Dikarenakan setiap bank memiliki intrumen pasar uang antar bank syariah yang dapat membantu Bank Syariah dalam menyelesaikan likuiditasnya. Sedangkan faktor internal lainnya yang mempengaruhi CAR ialah BOPO (Biaya Operasional terhadap Pendapatan Operasional, dapat dilihat dengan hasil estimasi sebagai berikut.

Tabel 3. Uji t BOPO terhadap CAR

Coefficients $^{\mathrm{a}}$

\begin{tabular}{|c|c|c|c|c|c|c|}
\hline \multirow{2}{*}{\multicolumn{2}{|c|}{ Model }} & \multicolumn{2}{|c|}{ Unstandardized Coefficients } & \multirow{2}{*}{$\begin{array}{c}\text { Standardized } \\
\text { Coefficients } \\
\text { Beta }\end{array}$} & \multirow[b]{2}{*}{$\mathrm{t}$} & \multirow[b]{2}{*}{ Sig. } \\
\hline & & B & Std. Error & & & \\
\hline 1 & (Constant) & 33.909 & 4.059 & & 8.353 & .000 \\
\hline & BOPO & -.158 & .046 & -.527 & -3.399 & .002 \\
\hline
\end{tabular}

a. Dependent Variable: Capital Adequacy Ratio 
Dari hasil uji tabel 3 di atas dapat dilihat bahwa nilai signifikansi sebesar 0.002 maka dapat diketahui bahwa BOPO berpengaruh terhadap CAR. Apabila BOPO mengalami peningkatan sebesar $1 \%$ maka akan menurunkan CAR sebesar 0.158. Dapat diasumsikan semakin efisien bank menghasilkan laba melalui biaya operasionalnya, semakin meningkat pula modal yang ditanamkannya.

\section{SIMPULAN}

Dimasa pandemic covid-19 perbankan syariah mampu menunjukkan performanya sebagai lembaga keuangan syariah yang terus berkembang dilihat dari data perkembangan Aset dan pertumbuhan DPK. Bank yang sehat akan memiliki modal yang cukup yang dilihat dari rasio kecukupan modal (Capital Adequacy Ratio / (AR). Dalam Rasio Kecukupan Modal Perbankan Syariah tidak memiliki dampak yang terjadi di masa pandemic covid-19, CAR perbankan syariah periode tahun 2020 tetap berada pada level yang cukup kuat meskipun dalam keadaan pandemi covid-19., meskipun Industri Perbankan Konvensional telah terdampak adanya pademi covid-19. Hal ini menunjukkan bahwa Bank Syariah mampu bertahan di saat terjadinya gejolak ekonomi di masa pandemic covid-19. Sedangkan salah satu faktor internal yang mempengaruhi CAR adalah Return On Asset (ROA) dengan nilai signifikansi sebesar 0.005 dan BOPO sebesar 0.002 nilai signifikansinya. Peningkatan pada ROA menyebabkan peningkatan pada CAR dan BOPO sebaliknya, semakin efisien biaya operasional yang dikeluarkan oleh bank syariah maka akan semakin meningkatkan CAR pada bank syariah.

\section{PUSTAKA ACUAN}

Amin Nurdin, Modal Bank Syariah Menebal, Optimalisasi di Masa Pandemi jadi Tantangan, bisnis.com, 2020

Arifin, Zainul. Dasar-dasarManajemen Bank Syariah. (Bandung: Alva Beta, 2002). Dendawijaya, L., Manajemen Pebankan (Jakarta : Ghalia Indonesia, 2011).

Ferdinandus, S. J., dkk (2020). Menilai Kondisi Kesehatan Keuangan Pt Bank Permata, Tbk Dimasa Pandemi Covid-19. 8, 22- 34. 
Hong, S.-J.; Najmi, H. The Relationships between Supply Chain Capability and Shareholder Value Using Financial Performance Indicators. Sustainability 2020, 12, 3130. https://doi.org/10.3390/su12083130

Kasmir, Pengantar Manajemen Keuangan (Jakarta: Kencana, 2009).

Mandiri, S., dkk (2013). Pengaruh Car, Fdr, Npf, Dan Bopo Terhadap Roe Bank Syariah Mandiri Periode Desember 2008Agustus 2012. Diponegoro Journal of Accounting, o(0), 320-328.

Muhammad (2002), Manajemen Bank Syariah, Yogyakarta: UPP AMP YKPN.

Muhammad (2014), Manajemen Dana Bank Syariah. Jakarta: Rajawali Pers.

Novitasari, D.R. (2015). Pengaruh Tingkat Kesehatan Bank Dengan Metode Camels Terhadap Pertumbuhan Laba Pada Bank Umum Syariah Periode 20112014, 1, 1-20.

Rahman, A. (2020). Analisis Pembiayaan Pada Masa Pandemic. Jurnal Ekonomi Islam, Vol 1 No. 2, 144-154. https://doi.org/10.30596/al-sharf.v

Rivai, Veithzal, dkk. Commercial Bank Management Manajemen Perbankan dari Teori ke Praktik (Rajawali Pers : Jakarta, 2013).

Rivai, Veithzal. Bank and Financial Institute Management. (Jakarta: PT. Raja GrafindoPersada, 2007).

Siamat, Dahlan. Manajemen Lembaga Keuangan, Edisi Empat (Lembaga Penerbit FEUI, 2004).

TA, C. M., dan Meutia Fitri, S.E, M.M, A. (2016). Pengaruh Biaya Operasional, Dana Pihak Ketiga Dan Non Performing Finance Terhadap Pertumbuhan Laba. Ilmiah Mahasiswa Ekonomi Akuntansi (JIMEKA), Vol. 1 No. 1, 247-257.

Wahyudi, Imam, dkk, Manajemen Risiko Bank Islam (Jakarta: Salemba, 2013).

Wilara, Giras Risti, dkk. Determinan Ketahanan Modal Bank Syariah di Indonesia : Pendekatan ECM, Jurnal Ekonomi dan Studi Pembangunan Volume17, Nomor. 2, Oktober, 2016.

Yulia, dan Ramdani, K. (2020). Pengaruh Dana Pihak Ketiga, Financing To Deposit Ratio, Non Performing Financing dan Tingkat Suku Bunga Terhadap Penyaluran Pembiayaan (Studi Kasus Perbankan Syariah di Indonesia Tahun 2011-2018). Journal of Islamic Economy and Business (JIsEB), 1(1), 63-75. http://e-journal.iainptk.ac.id/index.php/jiseb

Zulkifli, Sunarto. Panduan Praktis Perbankan Syariah, (Jakarta: Zikrul. Hakim, 2003) 